\title{
Uranium behaviour in the baboon after the deposition of a ceramic form of uranium dioxide and uranium octoxide in the lungs : implications for human exposure
}

\author{
H. METIVIER ${ }^{*}$, J.L. PONCY**, G. RATEAU**, G.N. STRADLING ${ }^{* * *}$,

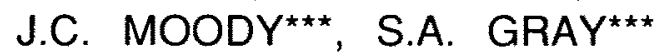

(Manuscrit reçu le 18 novembre 1991)

RÉSUMÉ Des quantités allant de 1 à 20 fois les LAl pour l'uranium (sous les formes chimiques $\mathrm{UO}_{2}$ et $\mathrm{U}_{3} \mathrm{O}_{8}$ ) ont été inhalées par des babouins suivis pendant 1 an par anthroporadiométrie puis sacrifiés pour analyse des différents organes où l'uranium peut migrer en quantité significative. Les résultats ont montré qu'un an après : 1) la rétention d'uranium dans le poumon est plus forte lorsqu'il est inhalé sous forme d' $\mathrm{OO}_{2}$ que sous forme d' $\mathrm{U}_{3} \mathrm{O}_{8}$; 2) le rapport "concentration dans les ganglions/concentration dans les poumons" est plus élevé lorsque l'uranium est inhalé sous forme d'UO $\mathrm{O}_{2}$; 3) pour les deux formes, le transfert vers les ganglions n'est pas influencé par la massé inhalée ; 4) les concentrations relatives d'uranium, quelles que soient les formes inhalées évoluent dans l'ordre : ganglions thoraciques > poumons >> crâne > fémurclavicule > vertèbres lombaires - cage thoracique $>$ sternum $>$ reins $>$ foie ; 5) la mesure de certains enzymes présents dans les urines peut être utile pour surveiller les surexpositions $\mathrm{d}^{\prime} \mathrm{U}_{3} \mathrm{O}_{8}$, mais, à ce jour et dans la gamme de doses étudiée, l'anthroporadiométrie et l'excrétion urinaire restent des procédés de choix.

ABSTRACT $\mathrm{UO}_{2}$ and $\mathrm{U}_{3} \mathrm{O}_{8}$ were inhaled by baboons in amounts such that the mass concentrations in the lungs were between about 3 and 20, and 1 and 7.4 times respectively those calculated in human lungs after exposure to $1 \mathrm{ALI}$ of the compounds. The results show that 1 year later: 1) the initial lung deposits of uranium retained in the chest are greater for $\mathrm{UO}_{2}$ than for $\mathrm{U}_{3} \mathrm{O}_{8} ; 2$ ) the ratios of the amounts of uranium retained in the lymph nodes vs those in the lungs, expressed both in terms of concentration and mass, are greater for $\mathrm{UO}_{2}$ than for $\mathrm{U}_{3} \mathrm{O}_{8} ; 3$ ) for both $\mathrm{UO}_{2}$ and $\mathrm{U}_{3} \mathrm{O}_{8}$, the amounts of uranium retained in the lymph nodes, expressed as a percentage of that in the chest, do not appear to be affected to a great extent by the initial lung deposits ; 4) after inhalation of $\mathrm{UO}_{2}$ and $\mathrm{U}_{3} \mathrm{O}_{8}$ in different amounts, the trend in the mass concentrations of uranium in the various tissues assayed were lymph nodes > lungs $>>$ skull > femoraclavicles > lumbar vertebra - thoracic cage > sternum > kidneys > liver ; 5) the measurement of urine concentrations of some enzymes may be a useful index for assessing substantial overexposures to $\mathrm{UO}_{2}$ and $\mathrm{U}_{3} \mathrm{O}_{8}$, however, so far, external chest monitoring and urinary assays of uranium should remain the procedures of choice.

\footnotetext{
* Commissariat à l'énergie atomique, Institut de protection et de sûreté nucléaire, BP 6 , 92265 Fontenay-aux-Roses Cedex, France.

** Commissariat à l'énergie atomique, Direction des sciences du vivant, BP 12, 91680 Bruyères-le-Chatel, France.

*** National radiological protection board, Chilton, Didcot, Oxon, OX11 ORQ, UK.
} 


\section{Introduction}

The most likely route of intake for workers exposed to $\mathrm{UO}_{2}$ and $\mathrm{U}_{3} \mathrm{O}_{8}$, which are important intermediates in the fabrication of nuclear fuels, is by inhalation. One method for assessing intakes of these compounds is by external monitoring of the chest. The interpretation of such measurements will be affected by the intake pattern, the amounts inhaled and individual biological variations. However, other factors such as the amounts of uranium assumed to have accumulated in the tracheobronchial lymph nodes and the possible influence of uranium deposited in the rib cage and skull after its translocation to the blood, will also be important.

At human autopsy, it is a common practice to estimate the skeletal content of uranium by extrapolation from that present in selected bones such as the femur. However, since the concentration of uranium in the skeleton is unlikely to be uniform, information on the variations that can occur between the bones is of practical value when using this method of assessment.

The evidence available suggests that the overall biokinetic behaviour of uranium in humans can be predicted reasonably accurately by combining data obtained on the translocation of uranium to blood in the rat with mechanical clearance data obtained from humans exposed to clay particles labelled with ${ }^{85} \mathrm{Sr}$ or ${ }^{88} \mathrm{Y}$ (Stradling et al.) [23-25]. However, in order to assess uranium distribution between the lung and thoracic lymph nodes, and to investigate uranium concentration in various bones of the skeleton, a large primate such as the baboon is the most appropriate animal species. In our experiments, the factors have been investigated after the administration of $\mathrm{UO}_{2}$ and $\mathrm{U}_{3} \mathrm{O}_{8}$ to male and female baboons in amounts corresponding to acute human exposure of between about 3 and 20 times the annual limit on intake (ALI) for class $Y$ uranium compounds as recommended by the International commission on radiological protection (ICRP) [15]. In addition, the study has included an investigation of urinary metabolites which could be used as biochemical indicators of uranium exposure.

\section{Materials and methods}

\subsection{Physico-chemical characteristics of uranium oxides}

Enriched ceramic grade $\mathrm{UO}_{2}\left(2.2 \%{ }^{235} \mathrm{U}\right)$, and $\mathrm{U}_{3} \mathrm{O}_{8}$ containing natural uranium $(0.71 \% 235 \mathrm{U})$, were obtained from nuclear fuel process lines. The oxide samples were first ground as a slurry in ethanol using a micronising mill with agate elements (McCrone research associates, London) to provide particles less than about $20 \mu \mathrm{m}$ in diameter. For the animal experiments, the respirable fractions of the dusts were separated from the milled samples by sedimentation in absolute ethanol. The particle size of 
the respirable fraction was determined at NRPB using an aerodynamic particle sizer (Model APS 33, TSI, Inc., St. Paul, MN, USA). The count median diameter (CMD) and mass median diameter (MMD) for $\mathrm{UO}_{2}$ particles were respectively $1.48 \mu \mathrm{m}$ (geometric standard deviation, $\sigma \mathrm{g}$ 1.37) and $2.19 \mu \mathrm{m}(\sigma \mathrm{g} \mathrm{1.32})$; the $C M D$ and $M M D$ for $\mathrm{U}_{3} \mathrm{O}_{8}$ particles were $0.82 \mu \mathrm{m}(\sigma \mathrm{g} \mathrm{1.24})$ and $1.29 \mu \mathrm{m}(\sigma \mathrm{g} 1.46)$.

\subsection{Animals}

Adult male and female baboons (Papio papio), weighing between 7.5 and $12 \mathrm{~kg}$ at the time of exposure were used. The health of the animals was confirmed by $X$-ray examinations of the lungs and biochemical analysis of the blood and urine. Dried food (U.A.R., Villemoison, France) supplemented with fresh fruits and water were freely available throughout the experiment.

\subsection{Exposure of animals to uranium oxides}

Eight baboons were used for the study. Groups of two animal (one male and one female) were exposed by inhalation to either $\mathrm{UO}_{2}$ or $\mathrm{U}_{3} \mathrm{O}_{8}$ in amounts that differed by about 1 order of magnitude.

Prior to inhalation of the oxides, the baboons were tranquilized by intramuscular injection of Valium (Roche, France; $0.5 \mathrm{mg} \mathrm{kg}^{-1}$ body wt) and anaesthetised by an intramuscular injection of Imalgene (Rhône Mérieux, France ; $10 \mathrm{mg} \mathrm{kg}^{-1}$ body wt). To facilitate administration of the aerosol, and maximise deposition in the pulmonary region of the lungs, a polythene tube (inner diameter $7.5 \mathrm{~mm}$ was first inserted into the trachea to the first bifurcation. To avoid external contamination during exposure, the anaesthetised animal was encapsulated in a polythene bag whilst breathing continued spontaneously via the tracheal tube.

The aerosol was generated from suspension of the oxides in isotonic saline $(2 \mathrm{~g}$ in $25 \mathrm{ml}$ or $0.3 \mathrm{~g}$ in $15 \mathrm{ml}$ at the higher and lower dose levels respectively) using a compressed air device (Acorn nebulizer, Medic-Aid, Pagham, UK). The animals were exposed for $2 \mathrm{~h}$ or $1,5 \mathrm{~h}$ respectively in a facility described in details by André et al. [4].

\subsection{Uranium assessment in the chest}

Uranium amounts in the chest were assessed from gamma spectrometric measurements of the 17,62, 92 and $185 \mathrm{keV}$ emissions from uranium. The measurements were made immediately after exposure to assess the initial lung content, and at 2, 7, 14, 30,62, 84, 140, 173, 210,281 and $365 \mathrm{~d}$ to evaluate the retention kinetics in the chest. The detection system inclued two sodium iodide crystals (type 121 SM 51, Scintiflex, $Q$ and $S$, Ltd) each protected by a $93 \mu \mathrm{m}$ thick beryllium window. The detectors, $130 \mathrm{~mm}$ apart, were located each side of the chest wall of the baboon whilst it was restrained in the sitting position. The 
counter was calibrated using a phantom in which known amounts of the oxides were embedded in tissue equivalent plastic. The data obtained for the chest uranium content was corrected by subtracting the amounts measured before exposure. The limits of detection of the counting system were $280 \mu \mathrm{g} \mathrm{UO} 2$ and $650 \mu \mathrm{g} \mathrm{U}_{3} \mathrm{O}_{8}$.

\subsection{Analysis of body tissues}

After killing the anaesthetised animals by exsanguination, the following tissues and bones of the skeleton were removed for assay of their uranium content : lungs, trachea minus connective tissue, thoracic lymph nodes, liver, kidneys, skull cap, sternum, clavicle, right and left sides of the thoracic cage, lumbar vertebra (5th), right and left femurs. After dissection, the samples were reduced in bulk by successive heat treatments at $500^{\circ} \mathrm{C}$ in a muffle furnace and digestion of the residue with $8 \mathrm{M} \mathrm{HNO}_{3}$. The residues were subsequently dissolved in $4 \mathrm{M} \mathrm{HNO}_{3}$ and analysed for their uranium content by delayed neutron counting. The procedure used was similar to that described in detail by Amiel, Donoghue et al., lde et al. $[1,9,13]$. The limit of detection (95\% confidence limits) using a statistical method [26] and based on a background count of $25 \mathrm{cpm}$ and a calibration

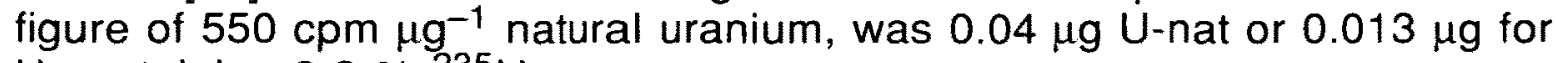
$\mathrm{U}$ containing $2.2 \%{ }^{235} \mathrm{U}$.

\subsection{Enzymatic analysis of urine}

The concentrations of some enzymes in urine can be used as indicators of the nephrotoxicity of uranium (Diamond, Leggett) $[8,19]$. In these experiments, the urine was tested for the presence of lactate dehydrogenase $(\mathrm{LDH})$ with the reagent Biotrol SFBC (Biotrol Pharma, France) and $\mathrm{N}$-acetyl- $\beta$-glucosaminidase (NAG) colorimetrically with Böehringer solution 875406 (Böehringer Mannheim, France). In the same urine samples, we also measured glutamic-oxaloacetic transaminase (SGOT) with Biotrol A03027, glutamic-pyruvic transaminase (SGPT) with Biotrol A03020, glutamyl gamma transferase (CGT) with Biotrol A03010 for the purpose of a complete health check of the baboons.

\section{Results}

\subsection{Initial lung deposits of uranium}

The initial lung deposits of uranium, as $\mathrm{UO}_{2}$, estimated for animals 607 , 608,609 and 616 , were respectively $17.5,18.2,2.66$ and $3.28 \mathrm{mg}$. The weights of the lungs, calculated from the equation "lung weight $(\mathrm{g})=$ $6.11 \times$ animal weight $(\mathrm{kg})+6.73$ " [20] were respectively $62.7,58.3,53.0$ and $66.0 \mathrm{~g}$. Hence, the amounts of uranium deposited in the lungs corresponded to about $19,21,3.3$ and 3.3 times the mass concentrations calculated to be in the pulmonary region of human lungs after acute exposute to the ALI for class $Y$ compounds of natural uranium 
$\left(1.5 \times 10^{3} \mathrm{~Bq}, 60 \mathrm{mg} U\right)$ [15]. This calculation assumes an AMAD of $1 \mu \mathrm{m}$, a pulmonary deposit of $25 \%$ of the amount inhaled [15] and a mass of the human lungs of $1000 \mathrm{~g}$ [14]. The initial lung deposits of uranium, as $\mathrm{U}_{3} \mathrm{O}_{8}$, for animals 611 and 617 were estimated to be respectively 5.30 and $8.05 \mathrm{mg}$; the values for animals 615 and 623 were estimated to be about $1 \mathrm{mg}$. The respective weights of the lungs were $79.4,72.1,69.6$ and $58.6 \mathrm{~g}$. Using the same method of calculation as above, the mass concentrations in the lungs were equivalent to respectively $4.5,7.4, \sim 0.96$ and $\sim 1.1$ times those predicted after the inhalation of $1 \mathrm{ALI}$ of a class $Y$ uranium compound. The relationships of the mass concentrations of uranium in the lungs $v s$ the ALI after inhalation of an aerosol of AMAD $5 \mu \mathrm{m}$ would be similar to the values above, since the lower fractional deposition in the pulmonary region, about $10 \%$, would be largely offset by the greater value of the $A L I$ under these conditions [15, 23].

\subsection{Uranium retention in the chest}

The amounts of uranium retained in the chest, expressed as a percentage of the initial lung deposits are shown in table I, and figure 1 for $\mathrm{UO}_{2}$ and figure 2 for $\mathrm{U}_{3} \mathrm{O}_{8}$. Attempts to express the retention data in terms of a two component exponential function using a weighted least-squares method [12] proved unsuccessful. This was due to the variability of the results in the early lung clearance phase and the difficulty in measuring uranium in the chest at later times. The data suggest that after the inhalation of $\mathrm{UO}_{2}$ at the high dose level, the long term retention half-times in the chest are about 350-400 d. At the high dose levels, the data show that $\mathrm{U}_{3} \mathrm{O}_{8}$ is more transportable than $\mathrm{UO}_{2}$. The plateaus observed in the chest retention data (tab. I, fig. 2) are most unlikely to reflect impairment of lung clearance. The data probably reflects errors in measurement of uranium in the chest, or movement of the uranium from the lungs to a transformed compartment or other body tissues. The results indicate that, for each exposure group, uranium is retained most avidly in the chest of the male baboons. However, since each group only contained one animal of either sex, it would be premature to draw any firm conclusions about the effect of sex on the lung retention kinetics of uranium. The difference observed here is probably due to hazard since this effect could not be confirmed when compiling all the results obtained with other particles such as beryllium metal, cobalt oxide or $\operatorname{UF}_{4}[2-3,5]$.

The apparent chest retention kinetics in baboons exposed to the lower amounts of $\mathrm{UO}_{2}$ and $\mathrm{UO}_{3}$ did not allow any conclusions to be drawn about the relative transportability of uranium. The values for $\mathrm{UO}_{2}$ are given in table $\mathrm{I}$, those for $\mathrm{U}_{3} \mathrm{O}_{8}$ are excluded since no significant decrease could be identified after the administration of about $1 \mathrm{mg}$.

\subsection{Tissue distribution of uranium in body tissues}

The amounts of uranium present in pre-selected body tissues and bones of the baboons after exposure to $U_{2}$ and $U_{3} O_{8}$ are given 
respectively in tables $\mathrm{III}$ and $\mathrm{IV}$, and tables $\mathrm{V}$ and $\mathrm{VI}$; the values have been corrected for the uranium present in the tissues of an unexposed animal (tab. II). The results are expressed in terms of the total amount of uranium present in the tissue $(\mu \mathrm{g})$, the relative concentration in that tissue ( $\mu \mathrm{g} \mathrm{kg}^{-1}$ wet wt) and the percentage of the initial lung deposit in that tissue (\% ILD). In each experimental group, similar amounts of uranium were administered to 1 female and 1 male baboon.

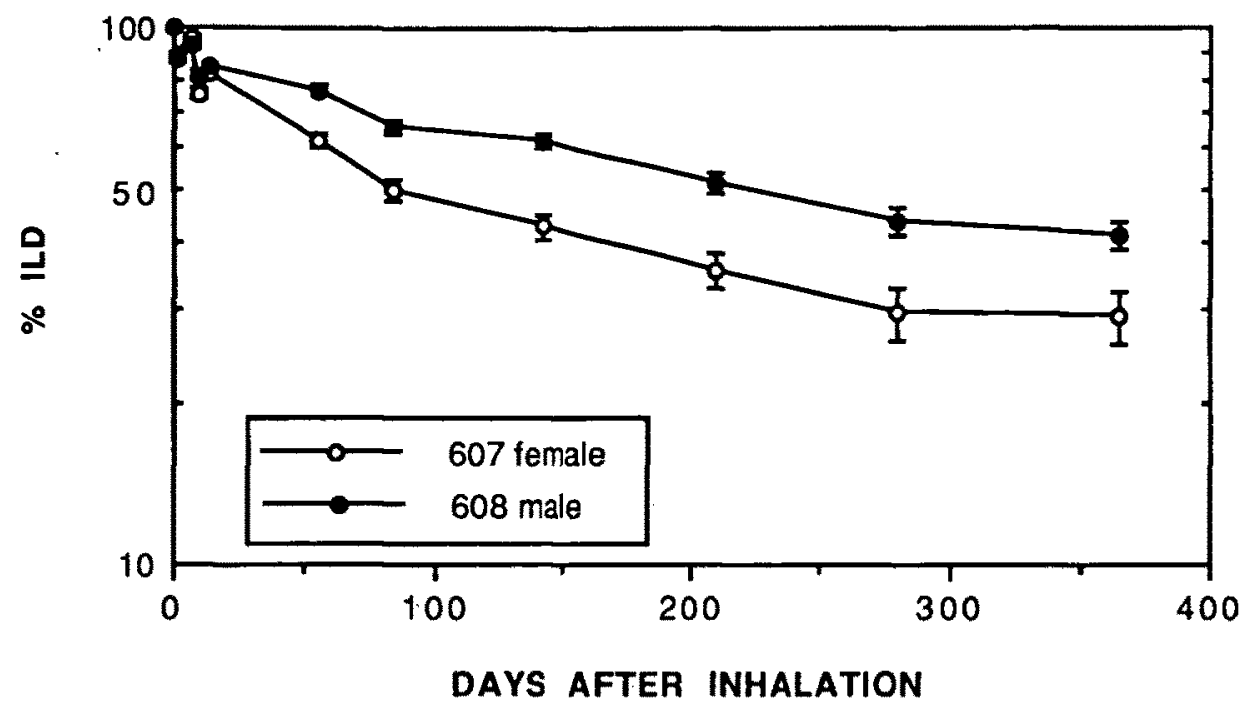

Fig. 1 - Retention of uranium in the chest after inhalation of $\mathrm{UO}_{2}(10 \mathrm{mg})$. Rétention thoracique après inhalation d'UO $\mathrm{O}_{2}(10 \mathrm{mg})$.

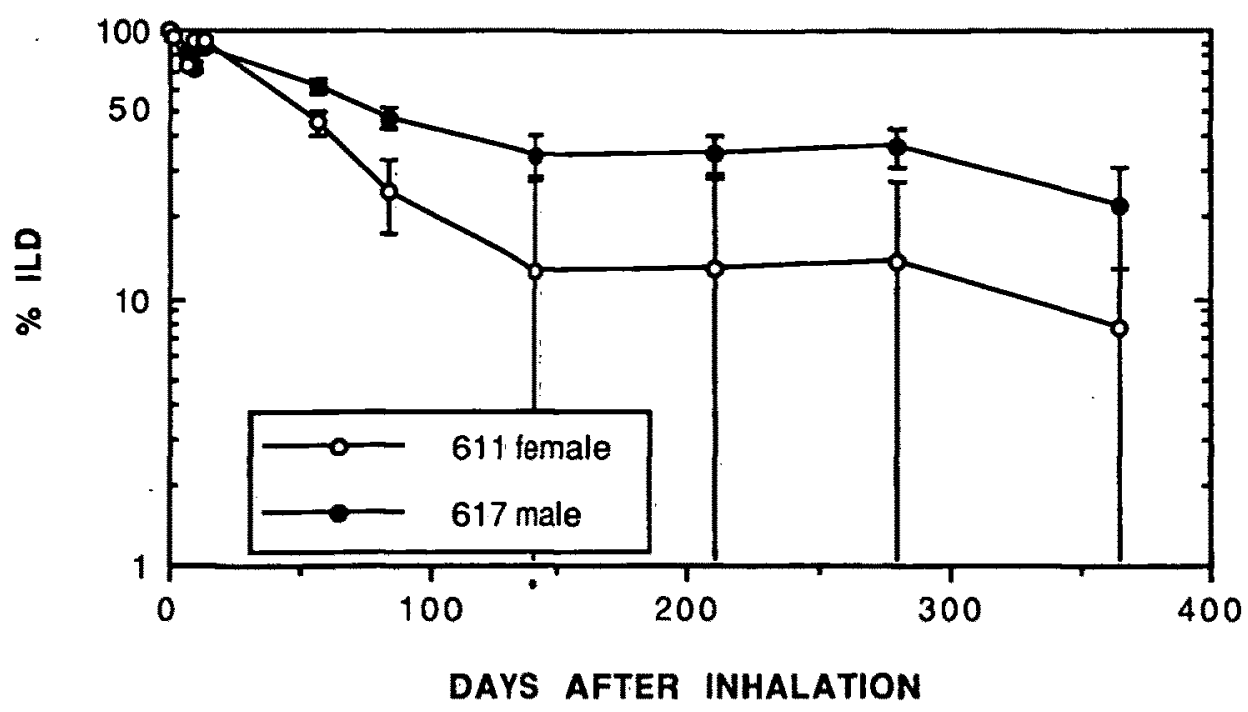

Fig. 2 - Retention of uranium in the chest after inhalation of $U_{3} \mathrm{O}_{8}(10 \mathrm{mg})$. Rétention thoracique après inhalation $d^{\prime} \mathrm{U}_{3} \mathrm{O}_{8}(10 \mathrm{mg})$. 
TABLE I

Retention of uranium in the chest. Rétention thoracique.

\begin{tabular}{|ccccccc}
\hline $\begin{array}{c}\text { Days after } \\
\text { inhalation }\end{array}$ & \multicolumn{2}{c}{ Uranium dioxide $\left(\mathrm{UO}_{2}\right)$} & Uranium octoxide $\left(\mathrm{U}_{3} \mathrm{O}_{8}\right)$ \\
\hline 2 & $\mathbf{6 0 7}$ & $\mathbf{6 0 8}$ & $\mathbf{6 0 9}$ & $\mathbf{6 1 6}$ & $\mathbf{6 1 1}$ & $\mathbf{6 1 7}$ \\
\hline 7 & $88 \pm 2$ & $87 \pm 2$ & $84 \pm 6$ & $101 \pm 5$ & $94 \pm 3$ & $102 \pm 2$ \\
14 & $95 \pm 2$ & $92 \pm 2$ & $95 \pm 6$ & $103 \pm 4$ & $75 \pm 3$ & $84 \pm 3$ \\
28 & $82 \pm 2$ & $85 \pm 2$ & $94 \pm 6$ & $91 \pm 5$ & $91 \pm 3$ & $87 \pm 3$ \\
56 & $76 \pm 2$ & $81 \pm 2$ & $98 \pm 6$ & $90 \pm 5$ & $92 \pm 3$ & $72 \pm 3$ \\
88 & $62 \pm 2$ & $77 \pm 2$ & $102 \pm 5$ & $97 \pm 5$ & $45 \pm 5$ & $62 \pm 4$ \\
140 & $50 \pm 2$ & $65 \pm 2$ & $91 \pm 6$ & $86 \pm 5$ & $25 \pm 8$ & $47 \pm 5$ \\
173 & $43 \pm 2$ & $62 \pm 2$ & - & - & $13 \pm 15$ & $34 \pm 6$ \\
210 & - & - & $74 \pm 7$ & $80 \pm 6$ & - & - \\
290 & $36 \pm 3$ & $52 \pm 2$ & $61 \pm 9$ & $79 \pm 6$ & $13 \pm 15$ & $35 \pm 6$ \\
365 & $30 \pm 3$ & $44 \pm 3$ & $44 \pm 12$ & $75 \pm 6$ & $14 \pm 14$ & $37 \pm 6$ \\
Sex & $29 \pm 3$ & $41 \pm 3$ & $29 \pm 17$ & $63 \pm 7$ & $8 \pm 23$ & $22 \pm 9$ \\
ILD mg U & $\mathrm{f}$ & $\mathrm{m}$ & $\mathrm{f}$ & $\mathrm{m}$ & $\mathrm{f}$ & $\mathrm{m}$ \\
\hline
\end{tabular}

Results are expressed as \% ILD (from $N(t)) \pm \frac{2 \sqrt{2 n}(t)}{N(t)} \%$

where $N(t)=$ nett chest count rate $(\mathrm{cpm})$ at $t$ days after subtraction of background count rate, $n(t)=$ gross chest count rate.

The results for $\mathrm{UO}_{2}$ administered at the higher dose levels (ILD 17.5 and $18.2 \mathrm{mg}$ uranium) given in table III have several noteworthy features. As expected, the largest amounts of uranium are present in the lungs and thoracic lymph nodes, although the amounts in the two animals varied appreciably. The largest amounts of uranium, other than in the lungs and lymph nodes, are present in the femora and skull cap. The concentrations of uranium in the various tissues and bones differ markedly and are in the order lymph nodes > lungs $>>$ skull cap > femora > clavicles > lumbar vertebra $\sim$ thoracic cage $>$ sternum $>$ kidneys $>$ liver. The concentration in the skull cap is about twice that in the femora and the difference between the skull cap and sternum about fivefold. The concentrations in the right and left thoracic cage are similar as are those for the right and left femora. The total amounts of uranium present in male tissues and bones are, in 
general, greater than in females, whereas the uranium concentrations in these tissues tend to be higher in females. This latter observation may reflect differences in mass between the sexes.

TABLE \|

Uranium content of tissues in unexposed baboon ${ }^{2}$. Teneur en uranium dans les tissus de babouin non exposé.

\begin{tabular}{|lccc|}
\hline \multicolumn{1}{c}{ Tissue } & $\mathbf{W t}^{\mathbf{b}}$ & \multicolumn{2}{c|}{$\begin{array}{c}\text { Uranium content } \\
\boldsymbol{g}\end{array}$} \\
\hline g $\mathbf{~ k g}^{-1}$
\end{tabular}

a) animal number 422 ; female ; wt at death $11.1 \mathrm{~g}$

b) wet weight

c) uranium content of trachea $0.08 \pm 0.01 \mu \mathrm{g}$

The results for $\mathrm{UO}_{2}$ administered at lower doses (ILD 2.66 and $3.28 \mathrm{mg}$ uranium) are given in table IV. In general, the amounts of uranium measured in the various body tissues and bones are about 1/6 of those in the previous experiment reflecting the difference in the initial lung deposits. However, when expressed as the percentage of the initial lung deposits, the amounts of uranium in the various tissues are similar to those found after the higher intake (tab. III). As in the previous experiment, the amounts of uranium in the lungs and lymph nodes differ markedly between the animals. Uranium concentrations in the various bones exhibit the same trend as at the higher dose level and, as before, the greatest amounts of translocated uranium are present in the skull caps and femora. In this case, both the concentrations and absolute amounts of uranium tend to be higher in males than in females. 


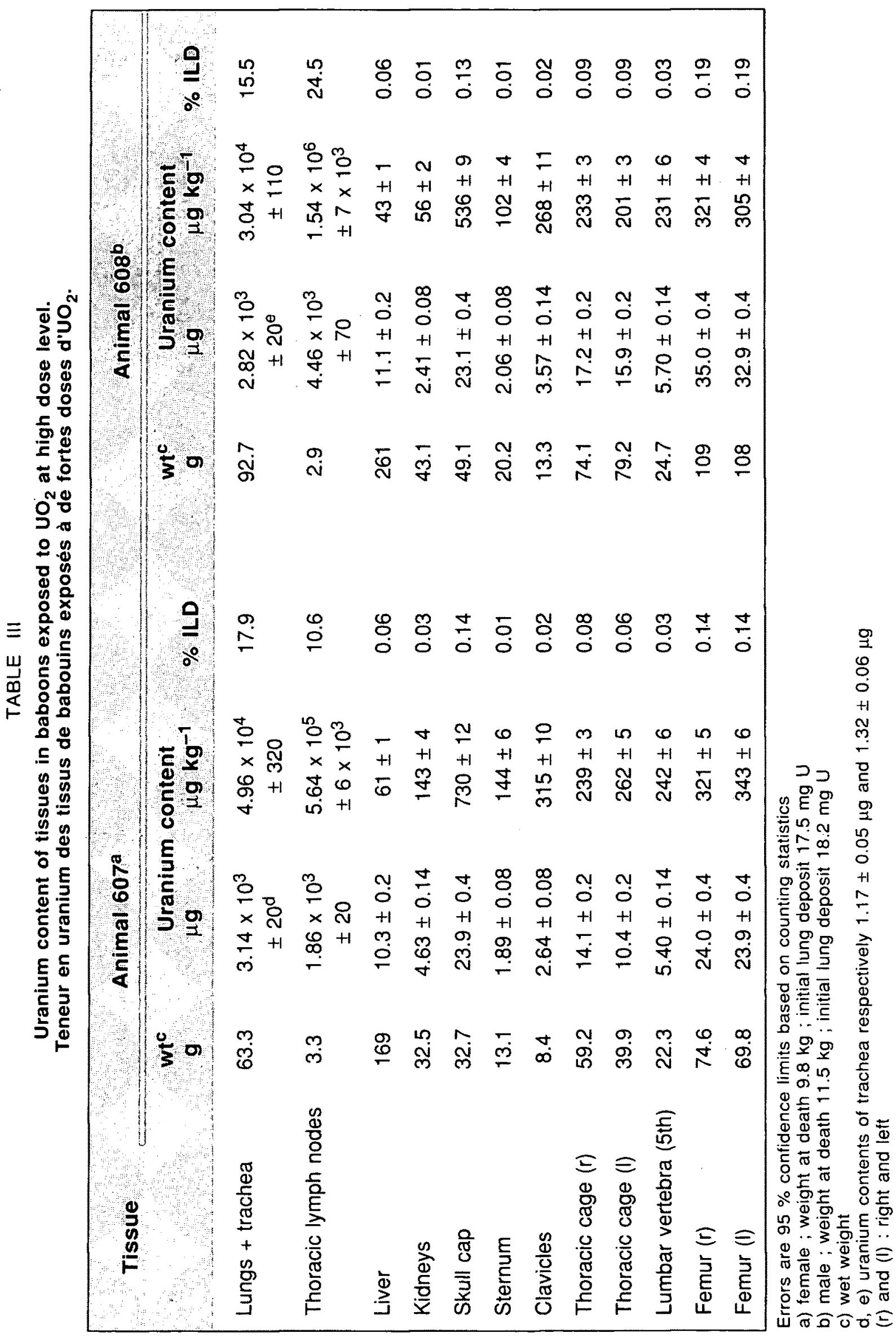




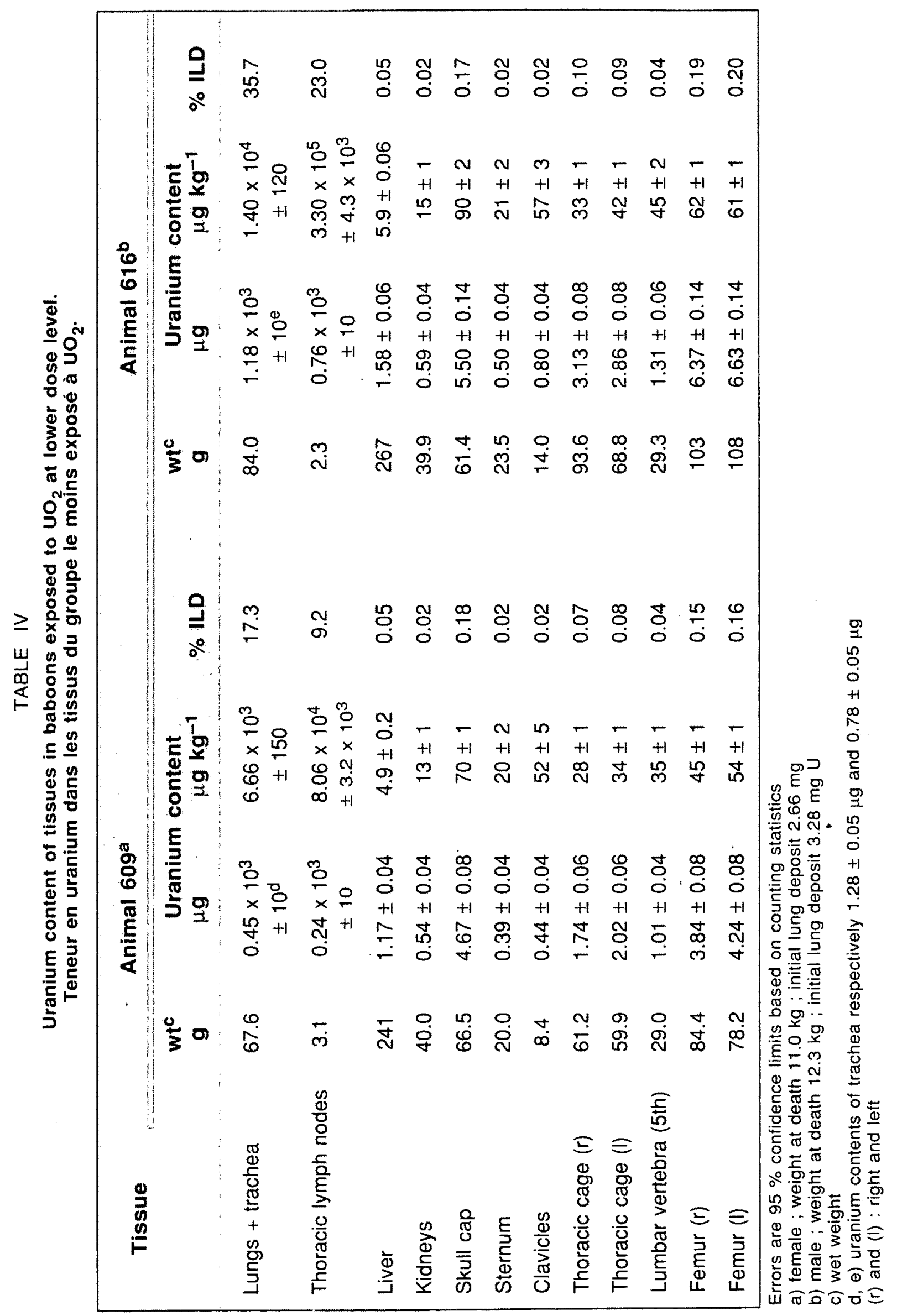


The data for uranium tissue distribution after $\mathrm{U}_{3} \mathrm{O}_{8}$ administration at the higher dose level $(5.3$ and $8.05 \mathrm{mg}$ ) are given in table $\mathrm{V}$. The trend in uranium concentration in the various tissues and bones, namely lymph nodes > lungs > skull cap > clavicles > femora > lumbar vertebra $\sim$ thoracic cage $>$ sternum $>$ kidneys $>$ liver is similar to that obtained after $\mathrm{UO}_{2}$ administration. The concentration in the skull cap is about 1.5 times that in the femora and clavicles, and about 5 times that in the sternum. The concentrations in the left and right femora, and in the left and right thoracic cage are similar, as before. However, uranium amounts in the various tissues, expressed as a percentage of the initial lung deposits, are about 3-6 times greater than after $\mathrm{UO}_{2}$ administration. This might be due to the greater transportability of uranium after $\mathrm{U}_{3} \mathrm{O}_{8}$ deposition in the lungs. In this case, the higher concentrations in the bones occur in the female baboons.

The results obtained after $\mathrm{U}_{3} \mathrm{O}_{8}$ administration at the lower dose level (ILD about $1 \mathrm{mg}$ ) are given in table VI. The amounts of uranium present in the various body tissues and bones are generally about 10-20 times lower than at the higher dose level. The fact that the amounts in the tissues are somewhat lower than expected on the basis of the differences in the initial lung deposits reflects uncertainty in the lower dose group measurements. However, the uranium concentrations in body tissues follow the same trend as in the higher dose group.

\subsection{Distribution of uranium between lungs and lymph nodes}

The ratio of the amounts of uranium present in the thoracic lymph nodes and lungs of each animal, expressed in terms of both concentration and mass, are given in table VII, together with the percentage of the total lung contents retained in the lymph nodes. All the data were calculated from those given in tables $\mid 1-\mathrm{VI}$. The results have five noteworthy features: 1) taking into account the different amounts administered, the ratios of uranium concentrations in the lymph nodes $v s$ lungs are greater after $\mathrm{UO}_{2}$ than after $\mathrm{U}_{3} \mathrm{O}_{8}$ administration; 2) after $\mathrm{UO}_{2}$ administration, the concentration ratio appears to be higher in males than in females but this trend was not observed for $\mathrm{U}_{3} \mathrm{O}_{8}$; however, since each exposure group consisted of two animals only, no conclusions are drawn as to the influence of sex ; 3) after the intake of each compound by each sex, the concentration ratios are reasonably independent of the amounts administered ; 4) taking into account the different amounts administered, the ratios, by mass, of uranium in the lungs $v s$ that in the lymph nodes are greater for $\mathrm{UO}_{2}$ than $\mathrm{U}_{3} \mathrm{O}_{8} ; 5$ ) for both $\mathrm{UO}_{2}$ and $\mathrm{U}_{3} \mathrm{O}_{8}$, the percentage of the lung deposits present in the lymph nodes at death does not appear to be substantially affected by the initial lung deposits, although the values for $\mathrm{U}_{3} \mathrm{O}_{8}$ are about 4-6 times lower than those for $\mathrm{UO}_{2}$. 


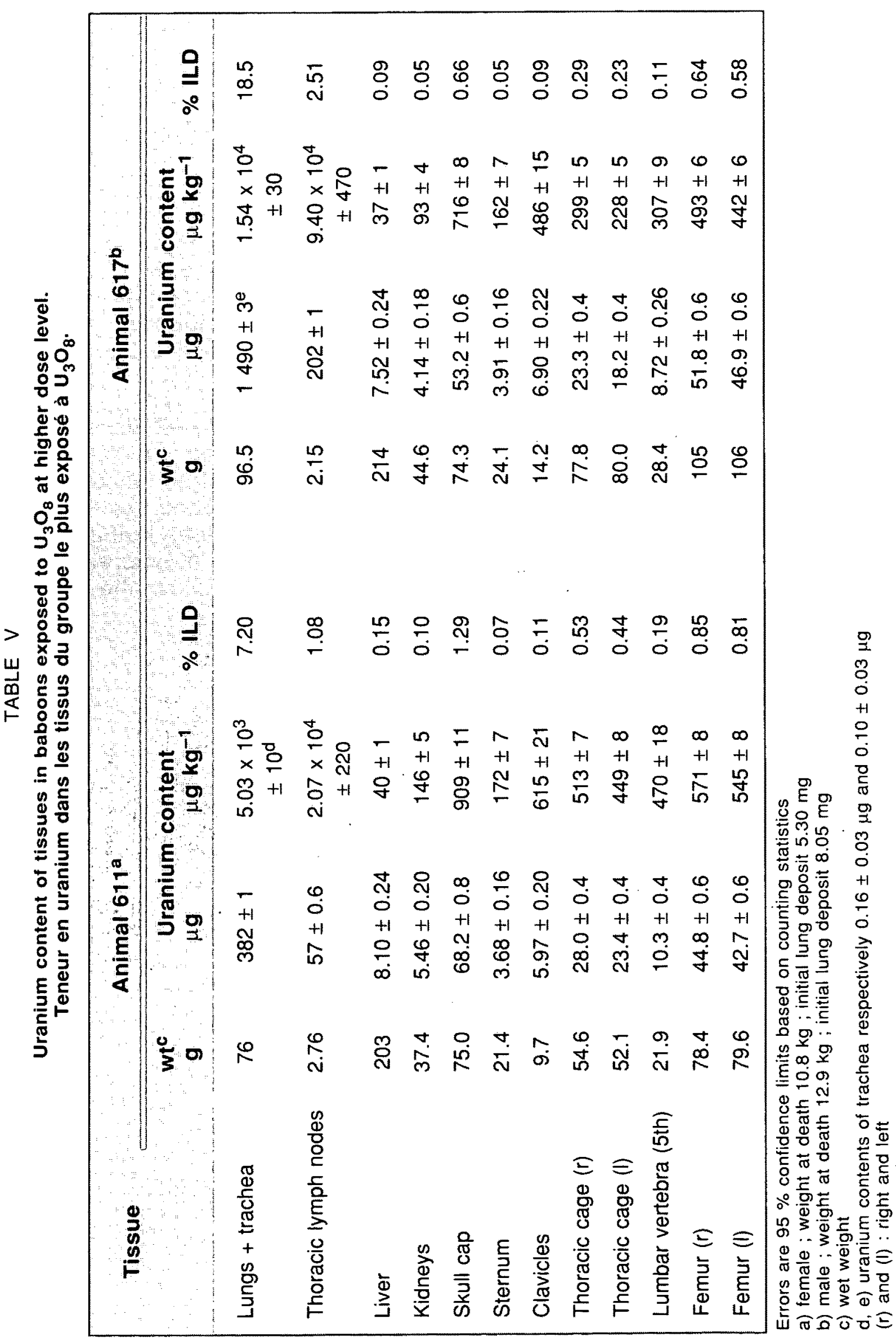




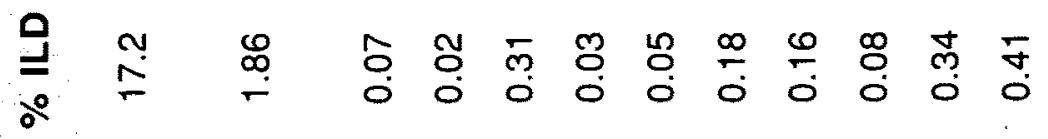

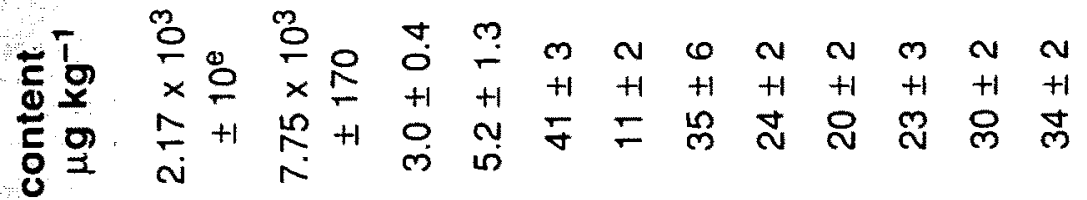

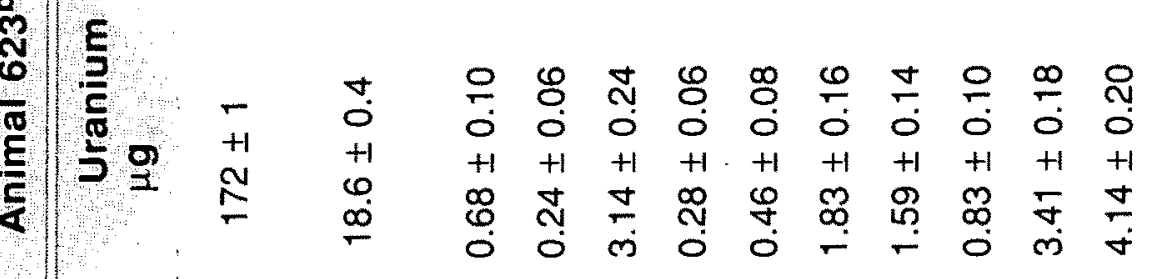

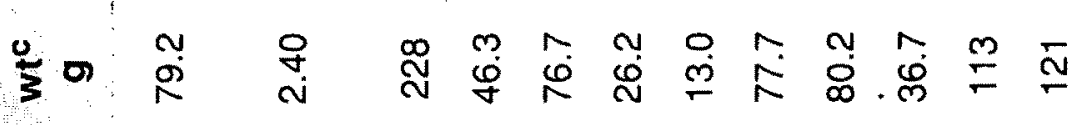

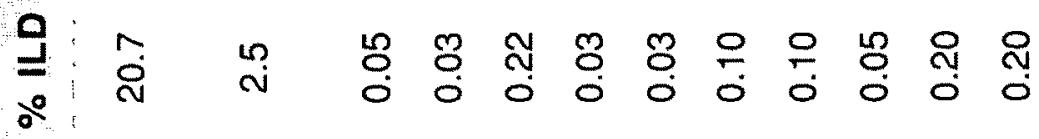

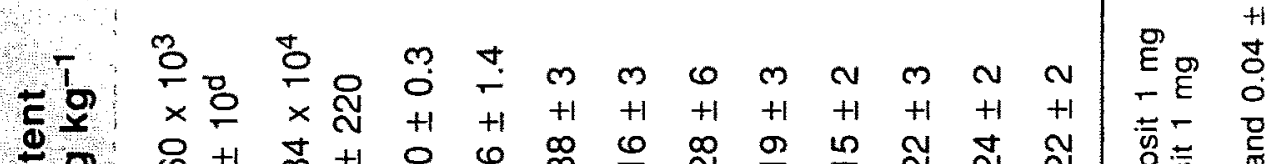

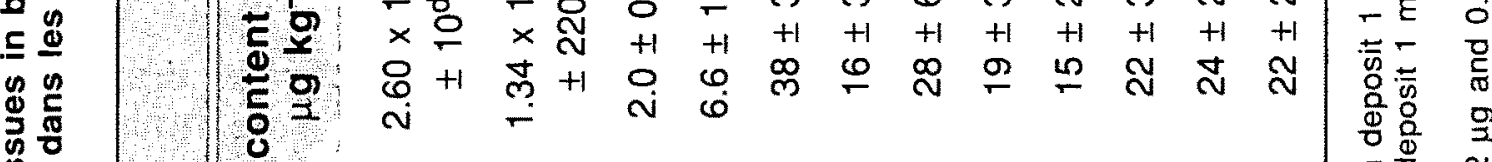

$\stackrel{\mathscr{O}}{=}$ 을

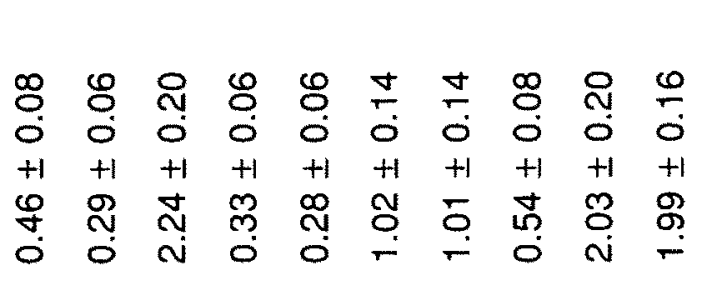

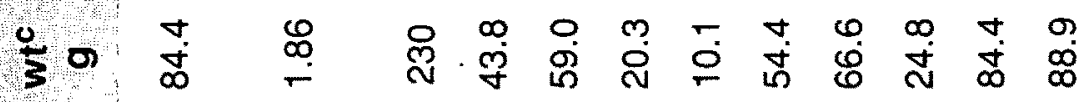

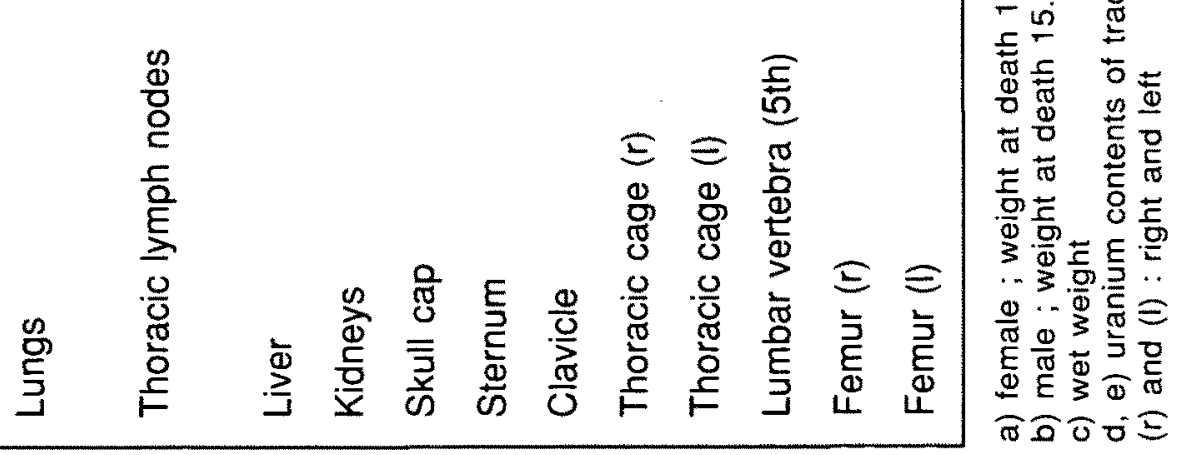


TABLE VII

Distribution of uranium between the lungs (L) and thoracic lymph nodes (TLN).

Distribution de l'uranium entre poumon (L)

et ganglions lymphatiques thoraciques (TLN).

\begin{tabular}{|lccccc|}
\hline Compound & $\begin{array}{c}\text { Animal No. } \\
\text { Sex }\end{array}$ & $\begin{array}{c}\text { ILD } \\
\text { mg }\end{array}$ & $\begin{array}{c}\text { Uranium ratio TLN : L conc. } \\
\text { by cy mass }\end{array}$ & $\begin{array}{c}\text { \% lung deposit } \\
\text { in TLN }\end{array}$ \\
\hline $\mathrm{UO}_{2}$ & $607, \mathrm{~F}$ & 17.5 & 11.4 & 0.59 & 37 \\
$\mathrm{UO}_{2}$ & $608, \mathrm{M}$ & 18.2 & 50.7 & 1.58 & 61 \\
$\mathrm{UO}_{2}$ & $609, \mathrm{~F}$ & 2.66 & 12.1 & 0.53 & 35 \\
$\mathrm{UO}_{2}$ & $616, \mathrm{M}$ & 3.28 & 23.6 & 0.64 & 39 \\
$\mathrm{U}_{3} \mathrm{O}_{8}$ & $611, \mathrm{~F}$ & 5.30 & 4.1 & 0.15 & 13 \\
$\mathrm{U}_{3} \mathrm{O}_{8}$ & $617, \mathrm{M}$ & 8.05 & 6.1 & 0.14 & 12 \\
$\mathrm{U}_{3} \mathrm{O}_{8}$ & $615, \mathrm{~F}$ & $\sim 1$ & 5.2 & 0.12 & 11 \\
$\mathrm{U}_{3} \mathrm{O}_{8}$ & $623, \mathrm{M}$ & $\sim 1$ & 3.6 & 0.11 & 10 \\
\hline
\end{tabular}

\subsection{Analysis of enzymes in urine}

Increases in the SGOT concentrations in urine (see 2.6) were observed after exposure of both males and females to the higher dose levels of $\mathrm{UO}_{2}$ (tab. VIII). The GGT concentrations were also increased in the male baboons exposed to the higher doses of $\mathrm{UO}_{2}$ und $\mathrm{U}_{3} \mathrm{O}_{8}$. The SGOT concentrations in the urine of unexposed animals (tab. VIIi) are compatible with those reported by Gerasimo et al. [10]. No increases in the urinary concentrations of the other enzymes investigated could be identified.

TABLE VIII

Enzymatic analysis of urine.

Analyse enzymatique de l'urine.

\begin{tabular}{|c|c|c|c|c|c|}
\hline \multirow[t]{2}{*}{ Animal } & \multirow[t]{2}{*}{ Compound } & \multirow{2}{*}{$\underset{(\mathrm{mg} U)}{\operatorname{ILD}}$} & \multirow[t]{2}{*}{ Enzyme } & \multicolumn{2}{|c|}{ Concentration in urine $\left(\mathrm{IU} \mathrm{I}^{-1}\right)^{a}$} \\
\hline & & & & Day 0 & Day 365 \\
\hline 607 & $\mathrm{UO}_{2}$ & 17.5 & SGOTb & 24 & 93 \\
\hline 608 & $\mathrm{UO}_{2}$ & 18.2 & SGOTb & 13 & 76 \\
\hline 608 & $\mathrm{UO}_{2}$ & 18.2 & $\mathrm{GGT}^{\mathrm{b}}$ & 69 & 91 \\
\hline 617 & $\mathrm{U}_{3} \mathrm{O}_{8}$ & 8.05 & GGTb & 50 & 137 \\
\hline
\end{tabular}

a) International units per litre

b) SGOT and GGT in unexposed animals, respectively 16-24 and 22-48 IU I-1 


\section{Discussion}

In these experiments, $\mathrm{UO}_{2}$ and $\mathrm{U}_{3} \mathrm{O}_{8}$ have been administered in varying amounts to baboons in order to elucidate the lung retention kinetics of uranium, its distribution between thoracic lymph nodes and lung tissue, its concentrations in various body tissues and bones, and its effect, if any, on metabolites present in urine. The results are now discussed in terms of their implications for human exposure.

\subsection{Uranium retention in the chest}

In-vivo monitoring data obtained for 9 individuals over a 12-year period after termination of their occupational exposure to ceramic grade $\mathrm{UO}_{2}$ have shown that the mean retention half-time of uranium in the chest is 390 d (range 280-490 d) (Stradling et al.) [25]. The values predicted from experiments in which the same compound was administered to rats ranged from 400 to $520 \mathrm{~d}$ and hence are in reasonable agreement with these observations. A feature of the human data is that an appreciable proportion of the chest content measured immediately after the cessation of exposure appears to be retained indefinitely and varies by about fourfold between individuals (Price) [21]. The results of the baboon experiments (tab. III, IV, VII) suggest that this must be due to the uranium retained in the thoracic lymph nodes rather than the data being affected by the small amounts of uranium that are likely to accumulate in the skull or rib cage as a consequence of uranium translocation into the blood. A twofold difference in uranium distribution between the lungs and lymph nodes is in reasonable agreeement with the fourfold variation in the apparent long-term component in humans. Whilst the magnitude of the lymph node content in baboons, about 35-60\% of the total lung content, is higher than the apparent value in humans, the discrepancy may be due to the difference in the exposure patterns, i.e. acute vs chronic, and the fact that the amounts of uranium deposited in baboon lungs were 1 order of magnitude or more greater than those measured in human lung.

$\mathrm{U}_{3} \mathrm{O}_{8}$ intakes by baboons were too low for the lung retention kinetics of uranium to be assessed with confidence by chest monitoring. The longterm retention half-time predicted for workers on the basis of Stradling's experiments with rats exposed to a similar $\mathrm{U}_{3} \mathrm{O}_{8}$ preparation suggests it would be about 230 d $[23,25]$. The baboon data quoted in tables V-VII suggest that the amounts of uranium likely to be retained indefinitely in the thorax as a consequence of accumulation in the lymph nodes will be appreciably lower after inhalation of $\mathrm{U}_{3} \mathrm{O}_{8}$ than after inhalation of $\mathrm{UO}_{2}$.

\subsection{Concentration ratios of uranium in lungs and lymph nodes}

The distribution of inhaled dusts between the thoracic lymph nodes and lungs is frequently expressed as a concentration ratio. The data in table VII show that the values for $\mathrm{UO}_{2}$ vary from about 11 to 50 and those for $\mathrm{U}_{3} \mathrm{O}_{8}$ from about 3 to 6 . It is noteworthy that ratios in excess of 100 have 
been reported by Leach et al. in dogs and monkeys exposed chronically to $5 \mathrm{mg} \mathrm{m}^{-3} \mathrm{UO}_{2}$ over an interval of $5 \mathrm{y}[17-18]$. The values reported for humans exposed to uranium are also extremely variable. Usually, however, they refer to uranium inhalation at low concentrations, but in many cases neither the chemical form nor the amounts inhaled have been specified. For example, concentration ratios of 1.5 have been reported after chronic inhalation to $\mathrm{U}_{3} \mathrm{O}_{8}$ (Donoghue et al. [9] ; 2.5 ( $\sigma \mathrm{g} \mathrm{5.5)}$ for 6 individuals exposed to undefined forms of uranium (Campbell et al. [6]) and 10.4 and 21.2 for 2 uranium millers (Singh et al. [22]). The relatively high values in the study reported here, particularly for $\mathrm{UO}_{2}$, reflect the possible consequences of human exposure to acute intakes of uranium in excess of the ALI for class $Y$ compounds. The data should not be extrapolated to predict the values that would occur after chronic inhalation of much lower amounts. The results summarised in table $\mathrm{VII}$ for $\mathrm{UO}_{2}$ suggest that the concentration ratio may be higher in males than in females with an opposite trend for $\mathrm{U}_{3} \mathrm{O}_{8}$. However, since only one animal of either sex was used at each dose group, the results should be interpreted with caution. Hence, no conclusions can be drawn from these experiments about the effect of sex on concentration ratios.

\subsection{Deposition in tissues other than the lung}

In general, the amounts of uranium present in the various bones of the baboon skeleton, expressed as percentages of the initial lung deposits, are about 5 times higher after $\mathrm{U}_{3} \mathrm{O}_{8}$ administration. This suggests that after intakes of $\mathrm{U}_{3} \mathrm{O}_{8}$ and $\mathrm{UO}_{2}$ the transfer rates of uranium to blood also differ by about fivefold. A similar difference in transfer rates was observed by Stradling et al. when the same preparations of the compounds were inhaled by rats [24].

It is noteworthy that after the inhalation of $\mathrm{UO}_{2}$ and $\mathrm{U}_{3} \mathrm{O}_{8}$ in different amounts by baboons of either sex, the trend in uranium concentration in the various bones and tissues is closely similar, namely skull > femora $\sim$ clavicles $>$ lumbar vertebra $\sim$ thoracic cage $>$ sternum $>$ kidneys $>$ liver. This appears to indicate that uranium is transported via the blood in the same chemical forms, i.e. complexed with transferrin, citrate and bicarbonate (Cooper et al.) [7]. In general, uranium concentrations in the skull cap are about 2 and 5 times that present respectively in the femora and sternum. The median concentration ratios are present in the clavicles, ribs and femora.

Other studies on the variability of uranium concentrations in human and animal tissues have also been published. The twofold difference in uranium concentrations in the ribs and sternum of a former uranium miner [22] were similar to those observed here for baboons. Welford and Baird [27] reported uranium concentrations in bone samples obtained from former residents of New York city ; the values varied from about $0.01 \mu^{-1}$ ash in the long bone shaft to about $0.03 \mu \mathrm{g} \mathrm{U} \mathrm{g}-1$ ash in the skull, and hands and feet. Hamilton [11] determined uranium concentration in skull, 
rib, femur (shaft), sternum, vertebra and cartilage samples from nonoccupationally exposed persons in the UK. The ash concentrations were respectively $0.032,0.020,0.024,0.018,0.017$ and $0.024 \mathrm{mg} \mathrm{g}^{-1}$, and would appear to be compatible with the results obtained in this study. Animal data also show that skeletal distribution of uranium is non-uniform. For example, after intravenous injection of the citrate complex into 3 dogs, the ratios of maximum vs minimum concentrations in the various samples of bone ash ranged from 4.2 to 12 [22].

The results of this study, and others, illustrate the possible errors that can occur in the assessment of the skeletal content of uranium by extrapolation from that present in individual bones, and demonstrate that the analysis of several bones will be necessary in order to make the best estimates. The baboon experiments suggest that Donoghue's assessments based on the sternum [9] could underestimate the skeletal content by about 2. The low concentrations of uranium present in the kidneys and liver $v s$ those in the bones in the baboon experiments are consistent with data obtained for former occupationally exposed individuals (Kathren et al.) [16].

\subsection{Enzymatic analysis of urine}

Increases in the concentrations of SGOT were observed in the urine of both baboons exposed to $\mathrm{UO}_{2}$ in amounts that simulated human exposures to about 20 times the ÁLI for the compound. No increase could be found after acute exposures in amounts equivalent to 3 times the ALI. Enhanced levels of GGT were found in the urine of the male baboons exposed to the higher doses of $\mathrm{UO}_{2}$ and $\mathrm{U}_{3} \mathrm{O}_{8}$, the latter being equivalent to 7.4 times the ALI. We are unsure whether these increases in concentration are due to uranium toxicity. No increases were observed in the urinary concentrations of those enzymes that reflect nephrotoxicity.

As a conclusion, presently, external monitoring of the chest and urine analysis should remain the methods of choice for this purpose.

\section{Acknowledgement}

The authors wish to acknowledge the excellent technical assistance provided by C. Duserre.

\section{REFERENCES}

[1] AMIEL S. - Analytical applications of delayed neutron emission in fissionable elements. Anal. Chem., 1962, 34, 1683-1692.

[2] ANDRE S., METIVIER H., LANTENOIS G., BOYER M., NOLIBE D., MASSE R. Beryllium metal solubility in the lung, comparison of metal and hot-pressed forms by in vivo and in vitro dissolution bioassays. Hum. Toxicol., 1987, 6, 233-240. 
[3] ANDRE S., METIVIER H., MASSE R. - An interspecies comparison of the lung clearance of inhaled monodisperse cobalt oxide particles. Part III : lung clearance of inhaled cobalt oxide particles in baboons. J. Aerosol Sci., 1989, 20 (2), 205-217.

[4] ANDRE S., ChARRUAU J., RATEAU G., VAVASSEUR C., METIVIER H. - Design of a new inhalation device for rodents and primates. J. Aerosol Sci., 1989, 20, 647656.

[5] ANDRE S., METIVIER H., AUGET D., LANTENOIS G., BOYER M., MASSE R. Lung dissolution of uranium tetrafluoride in rats and baboons. Comparison with dissolution by alveolar macrophages in culture and chemical dissolution. Hum. Toxicol., 1989, 8, 111-119.

[6] CAMPBELL E.E., McINROY J.F., SCHULTE H.F. - Uranium in the tissue of occupationally exposed workers. In : Proceedings from the Conference on Occupational health experience with uranium, Arlington VA, April 1975. Springfield : NTIS, 1976, 324-350.

[7] COOPER J.R., STRADLING G.N., SMITH H., HAM S.E. - The behaviour of uranium-233 oxide and uranyl nitrate in rats. Int. J. Radiat. Biol., 1982, 41, 421433.

[8] DIAMOND G.L. - Biological consequences of exposure to soluble forms of natural uranium. Radiat. Prot. Dosim., 1988, 26, 23-33.

[9] DONOGHUE J.K., DYSON E.D., HISLOP J.S., LEACH A.M., SPOOR N.L. Human exposure to natural uranium. Br. J. Ind. Med., 1972, 29, 81-89.

[10] Gerasimo P., duserRe C., MAthiEU J., FRITSCH P., MEtivier H. Biochemical monitoring of baboons treated with $L I C A M(C)$ after inhaling plutonium tributylphosphate. Radiat. Prot. Dosim., 1989, 26, 369-376.

[11] HAMILTON E.I. - The concentration of uranium in man and his diet. Health Phys., 1972, 22, 149-153.

[12] HEBDEN M.D. - Harwell subroutine library, compiled by HOPPER M.J. United Kingdom Atomic energy authority report AERE-R-7477, 1973, p. 71.

[13] IDE H.M., MOSS W.D., MINOR M.M., CAMPBELL E.E. - Analysis of uranium in urine by delayed neutrons. Health Phys., 1979, 37, 405-408.

[14] INTERNATIONAL COMMISSION ON RADIOLOGICAL PROTECTION (ICRP). Report of the task group on reference man. (ICRP Publication 23). Oxford : Pergamon press, 1975.

[15] INTERNATIONAL COMMISSION ON RADIOLOGICAL PROTECTION (ICRP). Individual monitoring for intakes of radionuclides by workers : design and interpretation. (ICRP Publication 54). Oxford : Pergamon press, 1988.

[16] KATHREN R.L., MCINROY J.F., MOORE R.H., DIETERT S.E. - Uranium in the tissues of an occupationally exposed individual. Health Phys., 1989, 57, 17-21.

[17] LEACH L.J., MAYNARD E.A., HODGE H.C., SCOTT J.K., YUILE C.L., SYLVESTER G.E., WILSON H.B. - A five-year inhalation study with natural uranium dioxide $\left(\mathrm{UO}_{2}\right)$ dust. 1.-Retention and biological effect in the monkey, dog and rat. Health Phys., 1970, 18, 599-612.

[18] LEACH L.J., YUILE C.L., HODGE H.C., SYLVESTER G.E., WILSON H.B. - A fiveyear inhalation study with natural uranium dioxide $\left(\mathrm{UO}_{2}\right)$ dust. II-Post-exposure retention and biologic effects in the monkey, dog and rat. Health Phys., 1973, 25, 239-258.

[19] LEGGETT R.W. - The behaviour and chemical toxicity or uranium in the kidney : a reassessment. Health Phys., 1989, 57, 365-383.

[20] METIVIER H., MASSE R., RATEAU G., NOLIBE D., LAFUMA J. - New data on the toxicity and translocation of inhaled ${ }^{239} \mathrm{PuO}_{2}$ in baboons. Radiat. Prot. Dosim., $1989,26,167-172$. 
[21] PRICE A. - Review of methods for the assessment of intake of uranium by workers at BNFL Springfields. Radiat. Prot. Dosim., 1989, 26, 35-42.

[22] SINGH N.P., BENNETT D.D., WRENN M.E., SACCOMANNO G. - Concentrations of alpha-emitting isotopes of $U$ and Th in uranium miners' and millers' tissues. Health Phys., 1987, 53, 261-266.

[23] STRADLING G.N., STATHER J.W., GRAY S.A., MOODY j.C., ELLENDER M., HODGSON A., SEDGWICK D., COOKE N. - The metabolism of uranium in the rat after inhalation of two industrial forms of ore concentrates. Hum. Toxicol., 1987, 6, 385-393.

[24] STRADLING G.N., STATHER J.W., GRAY S.A., MOODY J.C., HODGSON A., SEDGWICK D., COOKE N. - The metabolism of ceramic and non-ceramic forms of uranium dioxide after deposition in the rat lung. Hum. Toxicol., 1988, 7, 133139.

[25] STRADling G.N., STATHER J.W., PRICE A., COOKE N. - Limits on intake and interpretation of monitoring data for workers exposed to industrial uranium bearing dusts. Radiat. Prot. Dosim., 1989, 26, 83-87.

[26] SUMERLING T.J., DARBY S.C. - Statistical aspects of the interpretation of counting experiments designed to detect low levels of radioactivity. NRPB Report R-113. Chilton: National Radiological Protection Board, 1981.

[27] WELFORD G.A., BAIRD R. - Uranium levels in human diet and biological materials. Health Phys., 1967, 13, 1321-1324. 